\title{
UPAYA GURU PENDIDIKAN AGAMA ISLAM DALAM MENINGKATKAN BUDAYA RELIGIUS DI SMPN 44 BANDUNG
}

\author{
Fahrudin* \\ Endis Firdaus, Alhadi Shafiyullah \\ Universitas Pendidikan Indonesia, Indonesia \\ *E-mail: fahrudins59@upi.edu
}

\begin{abstract}
The role of the Islamic Religious Education teacher in learning is very important, especially in instilling students' religious values. With the application of the religious culture of students in daily life at school, it will have a major influence on the attitudes and practice of students' religious teachings in their daily life. In general, this study aims to describe the efforts of Islamic Education teachers in improving religious culture at SMPN 44 Bandung. Specifically, the purpose of this study is to describe the planning, implementation, constraints, and outcomes of the religious culture program at SMPN 44 Bandung. This research uses a qualitative approach with descriptive methods. The results of this study indicate that the PAI teacher in improving religious culture at SMPN 44 Bandung can be said to be quite successful, especially in changing the character or behavior of students.
\end{abstract}

Keywords: Islamic Education Teacher Efforts, Religious Culture, Islamic Education in Schools

Abstrak. Peranan guru Pendidikan Agama Islam dalam pembelajaran sangat penting, khususnya dalam menanamkan nilai-nilai religius siswa. Dengan diterapkannya budaya religius siswa dalam kehidupan sehari-hari di sekolah akan besar pengarubnya terbadap sikeap dan pengamalan ajaran agama siswa dalam kehidupan sehari-hari. Secara umum penelitian ini bertujuan untuk mendeskripsikan upaya guru PAI dalam meningkatkan budaya religius di SMPN 44 Bandung. Secara khusus tujuan penelitian ini adalab untuk mendeskripsikan perencanaan, pelaksanaan, kendala, dan hasil dari program budaya religius di SMPN 44 Bandung. Penelitian ini menggunakan pendekatan kualitatif dengan metode deskriptif. Hasil dari penelitian ini menunjukekan bahwa guru PAI dalam meningkatkan budaya religius di SMPN 44 Bandung ini bias dikatakan cukup berhasil, khususnya dalam merubah akblak atau perilaku siswa yang sebelumnya kurang baik menjadi baik.

Kata kunci: Upaya Guru PAI, Budaya Religius, PAI di Sekolah 


\section{PENDAHULUAN}

Selama satu dekade terakhir, masalah serius yang timbul dari beberapa negara di dunia ialah berkenaan dengan pembinaan budaya religius. Nagy (2010, hal. 60) menyimpulkan dalam penelitiannya bahwa di California, sebagian elemen masyarakat beragama budha mulai kehilangan norma-norma religius. Pasalnya di daerah tersebut telah terjadi pemisahan norma-norma agama dengan kehidupan sehari-hari. Sebab pemerintah Amerika telah mencanangkan untuk tidak mendukung program keagamaan sebagai pembinaan karakter religius khususnya di sekolah-sekolah umum.

Spira et al., (2004, hal. 7) dalam penelitiannya menyimpulkan bahwa di Kanada, nilai-nilai religius justru dapat membawa dampak positif bagi kesehatan publik. Buktinya hukum agama setempat memberikan bantuan akses seluas mungkin kepada jutaan orang yang terinfeksi HIV/AIDS, baik berupa penyuluhan spiritual maupun memberi obat-obatan ARV khusus bagi penderitanya. Maka dari itu tidaklah heran jika agama banyak membawa dampak positif dalam berbagai persoalan hidup baik itu dalam hal kesehatan maupun pendidikan.

Dalam dunia pendidikan, sekolah pada hakikatnya merupakan lembaga yang bertanggung jawab dalam mencerdaskan kehidupan bangsa, dan hal tersebut selaras dengan penelitian Siregar (2017, hal. 1) bahwa sekolah menjadi wadah yang multi fungsi, dimana ia sebagai pusat tempat menimba ilmu pengetahuan, menerapkan nilai-nilai moral keadilan, kejujuran, kreatif, inovatif secara terintegrasi yang menghasilkan lulusan berkualitas tinggi dalam perkembangan intelektual, emosional dan spiritual di era digital teknologi yang semakin berkembang.

Adapun permasalahan yang timbul belakangan ini yaitu sebagian masyarakat memandang pembinaan keagamaan di sekolah telah mengalami kegagalan. Kemerosotan moral bangsa sering kali dipicu dengan semakin maraknya tawuran antar pelajar, kebiasaan mencontek saat ujian, perayaan kelulusan dengan berhurahura, bahkan bisa merembet pada perilaku para pejabat yang hobi korupsi, pedagang yang suka menipu dan perilaku negatif lainnya (Wening, 2012, hal. 56).

Selain itu masalah manajemen sekolah juga menjadi masalah klasik, apalagi jika dikaitkan dengan ranah prinsip-prinsip manajemen pendidikan Islam (Fakhruddin, 2011). Itulah sebabnya pelajaran agama di sekolah sering kali dijadikan biang kerok atas kemerosotan moral anak-anak bangsa di negeri ini. Oleh sebab itu peran guru sangatlah dibutuhkan dalam menyelesaikan permasalahan ini.

Guru menjadi faktor terpenting dalam proses pendidikan. Sebab, guru lah yang bertanggungjawab terhadap perkembangan jasmani dan rohani anak didiknya. Hal tersebut diungkapkan Muhlison (2014, hal. 47) dalam penelitiannya bahwa sebagai seorang pendidik, guru tidak semata-mata menjadi transformer of knowledge, akan tetapi juga menjadi transformer of value yang mampu membimbing dan menuntun siswa ke arah yang lebih baik (Asmarani, dkk.: 2019).

Dalam undang-undang R.I. Nomor 14 Tahun 2005 tentang guru dan dosen 
pada bab 1 pasal 1 dijelaskan: Guru adalah pendidik profesional dengan tugas utama mendidik, mengajar, membimbing, mengarahkan, melatih, menilai, dan mengevaluasi peserta didik pada pendidikan anak usia dini, pendidikan dasar, dan pendidikan menengah.

Dalam rangka menebarkan nilai-nilai kebaikan, Sanusi (2013, hal. 150) menilai seorang guru seharusnya bisa mencontohkan sikap religius pada siswanya dengan cara: 1) menebarkan ucapan salam, 2) menuntun siswa untuk mengutamakan shalat berjama'ah di sekolah, 3) mengajak siswa ikut dalam pengajian rutin dan baca tulis Alquran, 4) mengadakan kegiatan praktek ibadah, dan 5) memberikan kesempatan kepada siswa untuk silaturahim dengan guru-guru. Dengan adanya beberapa kegiatan yang berbasis religius diharapkan dapat menjadi wahana peningkatan karakter siswa. Karena dalam aplikasinya, semua siswa sudah dibiasakan dengan kegiatankegiatan yang religius, namun belum begitu membekas dalam diri siswa. Oleh karena itu, mengingat pentingnya penerapan nilai-nilai nuansa religius, maka peran guru sangatlah diperlukan.

Mengingat begitu pentingnya pendidikan budaya religius bagi peserta didik dalam proses membentuk sikap dan kebiasaan positif, peneliti tertarik untuk melakukan penelitian mengenai bagaimana peran guru PAI dalam meningkatkan budaya religius di sekolah. Untuk objek penelitian, peneliti memilih SMPN 44 Bandung, karena dalam studi pendahuluan, sekolah ini ternyata telah dinobatkan sebagai sekolah berbudaya religius di Kota Bandung pada akhir bulan desember tahun 2018 oleh Kepala Dinas Pendidikan Kota Bandung. Namun demikian, nyatanya penerapan budaya religius ini tidak sepenuhnya berjalan dengan optimal, disebabkan karena masih kurangnya kesadaran dari sebagian guru dalam mewujudkan sekolah yang religius.

Selain itu, masalah lainnya ialah tidak semua peserta didik yang paham akan pentingnya penerapan nilai-nilai religius bagi dirinya, walaupun pihak sekolah sudah melakukan berbagai upaya untuk meningkatkan karakter peserta didik agar menjadi insan yang patuh, taat, berilmu, beriman, bertakwa, dan berakhlak mulia. Akan tetapi semua itu belum bisa mencapai hasil yang diharapkan dan masih perlu tindakan tambahan dengan memaksimalkan potensi guru PAI yang nota benenya dianggap mampu untuk menanamkan nilai-nilai religius dan mengubah akhlak peserta didik ke arah yang lebih baik. Maka dari itu, peneliti tertarik untuk mengangkat tema dan sekaligus judul dalam penelitian skripsi mengenai bagaimana "Peran guru PAI dalam meningkatkan budaya religius di sekolah di SMPN 44 Bandung.

\section{METODE PENELITIAN}

Penelitian ini bermaksud untuk melihat fenomena yang terjadi di lapangan yang berkaitan dengan upaya guru Pendidikan Agama Islam dalam meningkatkan budaya religius siswa di SMPN 44 Bandung. Oleh karena itu, pendekatan yang digunakan ialah pendekatan kualitatif. Hal ini sesuai dengan pendapat Moleong (2005, hal. 20) bahwa pendekatan kualitatif itu peneliti bermaksud untuk memahami fenomenafenomena yang terjadi di lapangan. Adapun metode yang digunakan dalam penelitian ini ialah metode deskriptif. 
Peneliti memilih metode ini karena peneliti akan mendeskripsikan fenomenafenomena yang ditemukan dan menggambarkan dengan rinci apa-apa yang ditemukan di lapangan. Hal ini sejalan dengan apa yang dikemukakan oleh Hamdi dan Bahruddin (2014, hal.5) bahwa metode deskriptif itu ialah suatu metode penelitian untuk menggambarkan fenomena-fenomena yang ada sesuai dengan fakta dan realita atau apa adanya.

Adapun yang menjadi sumber data utama dalam penelitian ini adalah guru PAI di SMPN 44 Bandung. Selain itu, juga kepala sekolah, wakasek kurikulum dan wakasek kesiswaan. Kemudian sebagai sumber data sekunder yaitu wawancara dengan siswa ditambah dengan dokumen-dokumen penting yang menjadi pendukung, serta hasil observasi pada lingkungan SMPN 44 Bandung. Hal ini sesuai dengan pendapat Arikunto (2006, hal. 11) yang merumuskan bahwa data primer (data asli atau data up to date) diperoleh atau dikumpulkan oleh peneliti secara langsung dari sumber datanya dan data sekunder sebagai data pendukung atau penunjang penelitian. Sedangkan sumber data sekunder bisa berupa dokumen, arsip, buku, karya ilmiah lainnya serta foto kegiatan belajar mengajar.

Data yang terkumpul kemudian dianalisis dengan menggunakan metode deskriptif kualitatif yang meliputi; data reduction, data display, dan conclusion drawing/verification. Data kualitatif dapat direduksi dan ditransformasikan dalam banyak cara, yaitu: melalui seleksi halus, melalui rangkuman melalui suatu pola yang besar dan seterusnya (Emzir, 2011, hal. 130).
Untuk menganalisis transkip wawancara, catatan lapangan observasi, dan studi dokumentasi maka diperlukan koding hasil penelitian. Dalam penelitian kualitatif penyajian data ini dapat dilakukan dalam bentuk table, grafik, phie chard, pictogram, dan sejenisnya. Melalui penyajian data tersebut, maka data terorganisasikan, tersusun dalam pola hubungan, sehingga akan semakin mudah dipahami (Sugiyono, 2012, hal. 95).

Kemudian peneliti melakukan verifikasi data yang telah didapat dari awal hingga akhir proses penelitian. Peneliti melakukan hal ini untuk mendapatkan sebuah kesimpulan yang dapat diuji kebenarannya berdasarkan penyajian data yang diperoleh dari informan yang menjadi objek penelitian di lapangan.

Pada setiap penemuan baru dalam sebuah penelitian tentunya harus di uji keabsahannya agar hasil penelitian dapat dipertanggung jawabkan kebenarannya dan dapat dibuktikan. Maka dari itu untuk mengecek keabsahan temuan teknik yang dipakai peneliti adalah teknik triangulasi. Triangulasi ialah sebuah teknik pengumpulan data yang bersifat menggabungkan dari berbagai teknik pengumpulan data dan sumber yang telah ada (Sugiyono, 2012, hal. 83).

Peneliti melakukan uji keabsahan data kepada Kepala Sekolah, atau kepada salah satu guru Agama yang ada di SMPN 44 Bandung. Sebab peneliti yakin bahwa mereka ini mampu memberikan penguatan dan kebenaran data terhadap hasil temuan peneliti selama berada di lapangan. 


\section{HASIL PENELITIAN DAN PEMBAHASAN}

1) Profil SMPN 44 Bandung

SMPN 44 Bandung awalnya dibangun pada tahun 1962. Sekolah ini awalnya bernama Sekolah Kepandaian Putri (SKP) yang berlokasi di I. Cimanuk No 1, Kelurahan Citarum, Kecamatan Bandung Wetan, Kota Bandung. Sekolah ini sempat terjadi beberapa perubahan nama menjadi: Sekolah Kesejahteraan Keluarga Pertama Negeri II (SKKPN II), SMPN 40 Bandung, SMPN 41 Bandung, SMPN 43 Bandung, dan terakhir SMPN 44 Bandung hingga sekarang.

Di samping itu, SMPN 44 Bandung juga mempunyai visi dan misi sekolah yang jelas. Visinya yaitu "Mewujudkan warga SMP Negeri 44 Kota Bandung yang agamis, berprestasi, kreatif, berbudaya lingkungan serta unggul dalam pembelajaran berbasis teknologi pada tahun 2020". Sedangkan misinya ialah "Melaksanakan pembelajaran yang membekali keterampilan dan kecakapan hidup berbasis teknologi, memberikan bekal dalam menghadapi tantangan kehidupan dan unggul menghadapi berbagai tantangan dalam era globalisasi, serta membentuk pribadi yang religius, agamis, berakhlak mulia, cerdas dan berpengetahuan luas".

Adapun kurikulum yang diterapkan di SMPN 44 Bandung ini ialah kurikulum 2013. Dimana kurikulum ini lebih berfokus penekanan pada kemampuan guru mengimplementasikan proses pembelajaran yang otentik, menantang dan bermakna bagi peserta didik, sehingga dengan demikian dapatlah berkembang potensi peserta didik sesuai dengan apa yang diharapkan oleh tujuan pendidikan nasional (Kurniaman \& Noviana, 2017, hal. 390).

Dalam Undang-Undang No. 20 Tahun 2003 pasal 3 tentang sistem pendidikan nasional yang menyebutkan bahwa pendidikan nasional bertujuan untuk mengembangkan potensi peserta didik agar menjadi manusia yang beriman dan bertakwa kepada Tuhan Yang Maha Esa, berakhlak mulia, sehat, berilmu, cakap, kreatif, mandiri, dan menjadi warga Negara yang demokratis dan bertanggung jawab (Fakhruddin, 2014, hal. 79). Maka dari itu, untuk mewujudkan cita-cita pendidikan nasional yang berfokus pada penerapan nilai-nilai karakter peserta didik, SMPN 44 Bandung telah membuat kebijakan sendiri yaitu dengan mengadakan program budaya religius. Program ini juga menjadi salah satu penunjang untuk mewujudkan visi dan misi sekolah. Bentuk perwujudan program budaya religius tersebut, SMPN 44 Bandung sudah menerapkan kegiatan pembiasaan sejak tahun 2005 hingga sekarang.

Selain itu, SMPN 44 Bandung ini merupakan salah satu sekolah percontohan di Kota Bandung dalam hal program religius. Sebab sekolah ini sudah lumayan lama merintis program tersebut, dan juga telah terbukti mendapatkan penghargaan sebagai sekolah religius sebanyak dua kali berturut-turut pada tahun 2017 dan tahun 2018 dari Dinas Pendidikan. Dengan demikian dapat disimpulkan bahwa bahwa sekolah SMPN 44 Bandung sudah benar-benar menerapkan nilai-nilai pendidikan karakter sesuai dengan standar tujuan pendidikan nasional, yang diimplementasikan melalui program budaya religius. 
2) Perencanaan Program Budaya

Religius di SMPN 44 Bandung

Dalam sebuah perencanaan, tentunya banyak hal yang harus dipikirkan terutama berkaitan dengan kebijakan, gagasan, latar belakang sejarah, tujuan, dan faktor-faktor lainnya yang dianggap bisa mendukung sebuah program. Sebagaimana Kusnawan (2010, hal. 918) menyimpulkan dalam penelitiannya bahwa perencanaan ialah suatu rangkaian proses kegiatan menyiapkan keputusan mengenai apa yang diharapkan terjadi (seperti peristiwa, keadaan, suasana dan sebagainya). Perencanaan bukanlah masalah kira-kira, manipulasi atau teoritis tanpa fakta atau data yang kongkrit, akan tetapi ia merupakan masalah yang membutuhkan persiapan matang untuk jangka panjang, supaya bisa terorganisir dengan baik dan sesuai rencana.

SMPN 44 Bandung sudah membuat suatu perencanaan yang matang untuk membuat program pembinaan karakter yang bernuansa religius. Hal tersebut telah divalidasi oleh kebijakan sekolah melalui visi dan misinya. Salah satu produk dari kebijakan sekolah ini ialah program budaya religius, yang mana program ini bertujuan untuk mendidik siswa supaya terbiasa dan merasa tidak asing dengan ajaran Islam, memberikan pengetahuan umum dan agama, serta juga menjadi jalan dalam meningkatkan sisi spiritual anak agar ia memiliki akhlak yang baik

Dika Rachman (guru PAI) mendefinisikan konsep ideal budaya religius itu ialah tidak hanya berfokus kepada program pembiasaan saja, akan tetapi lebih diutamakan pada pembentukan akhlak, adab dan etika, yang bisa berdampak pada karakter anak didik. Kemudian yang namanya budaya religius tentu perlu adanya pengamalan terhadap nilai-nilai religius tersebut, supaya anak-anak didik kita bisa memiliki kepribadian yang sangat baik.

Selain itu, dalam pandangannya, Sudiono (guru PAI) menyimpulkan dasar dari perencanaan program budaya religius ini ialah sebagai langkah awal untuk kembali menerapkan model pendidikan di zaman Rasulullah saw. Sebab pada waktu itu, pendidikan lebih mengutamakan nilainilai akhlak dari pada mengutamakan ilmu pengetahuan. Alasannya cukup logis karena di zaman sekarang banyak sekali kita temukan orang-orang yang pinter tapi akhlaknya kurang. Mereka itu sama halnya seperti iblis, kenapa? Karena kalau kita menilai seseorang dari kepintaran, maka iblis pun jauh lebih pintar dari manusia, dan hanya saja dia tidak berakhlak. Maka dari itu model pendidikan di zaman Rasul tersebut, sangat perlu diterapkan di sekolah guna untuk mendidik siswa supaya bisa memiliki akhlak yang baik dan ilmu pengetahuan yang luas.

Selanjutnya, dalam pembuatan program budaya religius, sekolah melakukan perencanaan dengan menyusun langkah-langkah dan kegiatankegitan yang dapat diterapkan pada program budaya religius. Latar belakang pembuatan program ini tidak terlepas dari situasi dan kondisi sekolah. Pada tahun 2005 sekolah ini memiliki moral yang buruk. Sebab disekitar sekolah banyak sekali yang jualan minum-minuman keras, bahkan sering terjadi tawuran atau perkelahian antar siswa SMPN 44 Bandung. Selain itu juga ada geng motor yang suka mengganggu ketertiban di lingkungan sekolah. Oleh karena itu, rasa 
kekhawatiran terhadap anak didik di sekolah ini semakin meningkat. Untuk mengantisipasi terjadinya hal-hal yang tidak diinginkan, maka sekolah membuat sebuah perencanaan program pembinaan akhlak yang bernuansi religius.

Perencanaan dilakukan oleh pihak sekolah dengan melakukan musyawarah. Adapun pihak-pihak yang terlibat dalam perencanaan pembuatan program budaya religius di SMPN 44 Bandung yaitu Kepala Sekolah, guru-guru, para orang tua, dan seluruh elemen yang ada di SMPN 44 Bandung. Selain itu, faktorfaktor pendukung juga termasuk hal-hal yang dipertimbangkan seperti sarana prasarana, Sumber Daya Manusia (SDM), teknis kegiatan, metode yang tepat untuk digunakan, dan jumlah tenaga ahli (guru PAI) yang diperlukan untuk kelancaran pelaksanaan program. Oleh sebab itu seluruh proses perencanaan harus sesuai dengan aturan perencanaan yang ideal.

Proses perencanaan yang dilakukan pihak sekolah sudah sangat baik dalam mengadakan program budaya religius. Hal tersebut sejalan dengan yang diungkapkan Somantri (2014, hal. 2) bahwa perencanaan yang baik adalah perencanaan yang paling mungkin untuk dilaksanakan. Melalui perencanaan dapat dijelaskan tujuan yang ingin dicapai, ruang lingkup pekerjaan yang akan dijalankan, pihak-pihak yang terlibat, sumber daya yang diperlukan, serta langkah-langkah dan metode kerja yang dipilih berdasarkan urgensi dan prioritasnya.

Dari pemahaman di atas, maka dapat disimpulkan bahwa perencanaan ini memiliki enam pokok pikiran yaitu: pertama, perencanaan melibatkan proses penetapan; kedua, perencanaan harus mempertimbangkan latar belakang sebuah program; ketiga, perencanaan ditujukan untuk menutupi kesenjangan yang terjadi; keempat, perencanaan membutuhkan proses yang matang; kelima, perencanaan jangka panjang harus mempunyai banyak pilihan alternative; dan keenam, perencanaan yang baik ialah perencanaan yang sangat mungkin dilaksanakan.

Dengan demikian perencanaan program budaya religius di SMPN 44 Bandung telah dirancang dan disusun sebelumnya dengan cara musyawarah oleh seluruh pihak yang ada di lingkungan sekolah, guna untuk menyusun rangkaian kegiatan-kegiatan yang berhubungan dengan program budaya religius. Hal tersebut merupakan langkah yang tepat untuk meraih keberhasilan dari program budaya religius yang dilakukan di SMPN 44 Bandung.

3) Pelaksanaan Program Budaya

Religius di SMPN 44 Bandung

Pelaksanaan program budaya religius merupakan salah satu penerapan program kurikulum di SMPN 44 Bandung. Kegiatan tersebut bertujuan untuk meningkatkan mutu penyelenggaraan dan hasil pendidikan di sekolah yang mengarah pada pencapaian pembentukan karakter peserta didik yang bernuasa religius melalui kegiatan pembiasaan.

Kegiatan pembiasaan yang dilakukan oleh seluruh warga sekolah merupakan suatu upaya sekolah untuk mencegah terjadinya kemerosotan akhlak dikalangan siswa-siswi dan umumnya seluruh warga SMPN 44 Bandung dengan mengikuti alur dari setiap kegiatan program budaya religius. Pelaksanaan kegiatan pembiasaan yang dilakukan oleh pihak sekolah SMPN 44 Bandung dilaksanakan secara 
terstruktur dan konsisten. Hal tersebut sesuai dengan konsep yang sebelumnya sudah direncanakan dengan matang. Proses pelaksanaan kegiatan pembiasaan itu terbagi menjadi empat bagian, yaitu di antaranya: 1) pembiasaan harian; 2) pembiasaan mingguan; 3) pembiasaan bulanan; dan 4) pembiasaan tahunan.

Dalam menerapkan program budaya religius, guru PAI merupakan motor atau penggerak dari program budaya religius tersebut, karena basis dari program pembiasaan ini ialah pendidikan agama Islam. Selain itu, keberadaan guru PAI di sekolah ini memang memiliki pengaruh yang sangat besar terhadap keberhasilan program budaya religius. Sebab ia secara tidak langsung telah mendukung kebijakan sekolah, dan juga menjadi ujung tombak dari visi misi sekolah agar bisa mencetak siswa-siswi yang berakhlak mulia.

Kemudian dalam program budaya religius terdapat beberapa kegiatan yang membuat siswa semakin dekat dengan Allah, senantiasa beribadah tepat waktu, dan mengajarkan nilai-nilai akhlak kepada siswa. Apabila dikaitkan dengan teori, hal tersebut sesuai dengan pendapat K. S. Putra (2015, hal. 17) bahwa program budaya religius merupakan bentuk pengamalan nilai-nilai agama Islam dalam kehidupan di sekolah dan di masyarakat, yang bertujuan untuk menanamkan nilainilai agama Islam yang diperoleh siswa dari hasil pembelajaran di sekolah, agar menjadi bagian yang menyatu dalam perilaku siswa sehari-hari. Selain itu, budaya religius juga diartikan Fathurrohman (2016, hal. 27) sebagai upaya terwujudnya nilai-nilai ajaran agama yang menjadi sebuah tradisi dalam berperilaku dan budaya organisasi yang diikuti oleh seluruh warga di lembaga pendidikan.

Berikutnya, Supriyanto(2018, hal. 469) mendefinisikan program budaya religius sebagai sebuah gagasan atau pikiran manusia yang bersifat abstrak kemudian diaplikasikan atau diwujudkan melalui perilaku manusia yang berlandaskan nilai-nilai keagamaan. Dari sekian pemaparan teori, maka dapat disimpulkan bahwa budaya religius merupakan sebuah upaya untuk menerapkan nilai-nilai yang bersifat keagamaan dan sudah menjadi kebiasaan/ tradisi.

Pelaksanaan program budaya religius yang ada di lembaga pendidikan, pada umumnya bermula dari gagasan dan dukungan dari berbagai pihak, kemudian diterapkan dalam menciptakan suasana religius yang disertai penanaman nilainilai pendidikan karakter religius secara istikamah. Penerapan program budaya religius di SMPN 44 Bandung melalui kegiatan pembiasaan sudah dirintis sejak belasan tahun yang lalu dimulai dengan program membiasakan siswa muslim untuk terbiasa memulai hari dengan tepat waktu kemudian membiasakan dengan kegiatan berikut:

1. Pembacaan surat $\mathrm{Al}$-fatihah

2. Pembacaan sayyidul Istighfar

3. Pembacaan shalawat Nariyah

4. Pembacaan ayat Kursi

5. Pembacaan 3 ayat terakhir surat al.baqarah

6. Pembacaan do'a nabi yunus

7. Pembacaan ayat trakhir surat al.hasyr

8. Pembacaan asmaul husna

9. Pembacaan membaca 4 ayat surat yasin,ar.rahaman, waqiah dan mulk

10. Kultum yang disampaikan oleh perwakilan siswa atau siswi. 
Lebih lanjut, K. S. Putra (2015, hal. 30) merangkum perwujudan budaya religius (religious culture) merupakan sebagai bentuk upaya yang dilakukan guru PAI dalam pengembangan nilai karakter religius di sekolah. Bentuk perwujudan itu di antaranya meliputi; (1) melakukan tadarus Alquran; (2) shalat dhuhur dan shalat Jum'at berjama'ah; (3) tali asih; (4) iuran qurban; (5) pesantren kilat di bulan ramadhan; (6) bakti sosial; mengadakan kantin kejujuran; peringatan hari besar Islam; (9) peduli lingkungan; (10) halal bihalal; (11) budaya 5 S (senyum, salam, sapa, sopan, dan santun); (12) Istighosah dan do'a bersama. Menurutnya budaya tersebut terbukti dapat meningkatkan spiritualitas siswa, rasa persaudaraan dan toleransi antar sesama, kedisiplinan dan kesungguhan dalam belajar, serta dapat mempererat ikatan silaturrahmi antara guru dan siswa.

Kemudian Aulia (2016, hal. 322) menyimpulkan dalam penelitiannya bahwa pelaksanaan budaya religius dapat dilakukan melalui kegiatan pembiasaanpembiasaan di sekolah dan di rumah seperti mengurus seluruh kegiatan kantin, PBB, shalat berjaamah, tahfidz dan kegiatan-kegiatan yang ada di syiar bulanan. Berdasarkan beberapa penjelasan diatas maka dapat disimpulkan bahwa mewujudkan budaya religius merupakan suatu tindakan yang terpuji, mengingat kata religius berarti berhubungan dengan norma-norma agama yang dilandasi perilaku, sehingga menjadi tradisi atau kebiasaan sehari-hari, dan dapat diaplikasikan oleh seluruh warga sekolah, masyarakat, atau pemerintah.

Pelaksanaan program budaya religius di SMPN 44 Bandung dilakukan dengan cara pendekatan langsung, di mana para guru PAI sebagai pembina utama bertemu dan bertatap langsung dengan para siswa yang sekaligus sebagai objek dari kegiatan pembiasaan. Dalam teorinya, Muchith (2016, hal. 233) merumuskan bahwa Guru PAI profesional adalah guru yang mahir dalam memberikan motivasi belajar, terampil menggunakan metode dan pendekatan pembelajaran, ahli dalam melakukan gaya mengajar yang bervariasi, rajin melaksanakan pengabdian atau melayani masyarakat, terampil dalam memberikan pemahaman nilai-nilai ajaran Islam kepada masyarakat dan peserta didik.

Selain itu Nasir (2013, hal. 194) juga menyimpulkan hasil penelitiannya bahwa dalam melaksanakan tanggung jawab penguasaan bidang studi, seorang guru PAI yang profesional dituntut untuk memiliki kemampuan memahami peserta didik, merancang pembelajaran, melaksanakan proses pembelajaran yang mendidik, dan melakukan evaluasi pembelajaran. Dengan demikian, hal tersebut merupakan upaya-upaya yang dirancang dan dilaksanakan sistematis untuk menanamkan nilai-nilai karakter religius pada peserta didik yang berhubungan langsung dengan Tuhan Yang Maha Esa, dan juga berhubungan kepada sesama manusia, serta lingkungan kehidupannya.

Berdasarkan penjabaran di atas, maka dapat disimpulkan bahwa pelaksanaan program budaya religius di SMPN 44 Bandung merupakan upaya untuk mencegah berkembangnya kemerosotan akhlak pada siswa-siswi SMPN 44 Bandung, selain itu program ini juga merupakan usaha yang dilakukan oleh sekolah untuk memfasilitasi para 
siswanya agar bisa memiliki akhlak yang baik. Dan dibalik kelancaran pelaksanaan program ini, ada peran guru PAI yang paling berpengaruh dalam merealisasikan nilai-nilai Islam kepada peserta didik.

4) Kendala Yang Dihadapi dalam Mewujudkan Budaya Religius di Sekolah

Dalam menjalankan sebuah program kegiatan yang dilakukan oleh sebuah organisasi atau instansi, tentunya pasti akan mengalami beberapa kendala dalam proses penyelenggaraan kegiatan tersebut. Begitupun juga dengan pelaksanaan program budaya religius yang dilakukan guru PAI di SMPN 44 Bandung, besar kemungkinan mengalami berbagai kendala, yaitu di antaranya:

a. Masih ada sebagian guru dan yang merasa terganggu waktunya itu dengan pembiasaan ini karena perbedaan faham.

b. Kurangnya semangat dan motivasi dari siswa untuk mengikuti kegiatan pembiasaan.

c. Masalah kedisiplinan siswa.

d. Sempat mendapat penolakan dari para orang tua siswa terhadap kebijakan sekolah dalam menerapkan program budaya religius.

e. Masalah sarana prasarana yang kurang mendukung.

f. Faktor teknisi yang kurang memadai

g. Jumlah tenaga ahli yang terbatas

Seharusnya sekolah dapat memenuhi segala kebutuhan yang bisa mendukung pelaksanaan program budaya religius, sebab ia merupakan sebuah sistem sosial kompleks sebagai lembaga penyelenggara pendidikan yang memiliki tugas dan tanggung jawab. Sebagaimana Muhaimin
(2006, hal. 106) menyimpulkan bahwa sekolah bertanggung jawab dalam menciptakan suasana atau iklim sekolah dengan yang religius. Salah satu cara untuk menciptakan suasana sekolah yang religius yaitu dengan mewujudkan program budaya religius.

Hal tersebut senada dengan pendapat Sauri (2003, hal. 45) bahwa sekolah tidak hanya berkewajiban pada pewarisan dan pelestarian nilai, tetapi juga menjadi lokomotif pembaharuan masyarakat atau agen of change, karena bagaimanapun sekolah merupakan wahana pembinaan manusia yang akan mengisi masa depan masyarakat. Kondisi dan situasi di masa depan berbeda dengan kondisi dan situasi hari ini. Karena itu orientasi sekolah adalah orientasi masa depan dengan segala perangkat sistem nilainya. Proses pembelajaran tidak berhenti pada penyampaian materi kurikulum, tetapi pengembangan dan reproduksi budaya dan kebiasaan baru yang lebih unggul seyogyanya dilakukan.

Program budaya religius yang diperankan oleh guru PAI di SMPN 44 Bandung ini cukup berjalan dengan lancar, meskipun dalam setiap kegiatan pembiasaan selalu ada saja kendala yang terjadi seperti masalah teknisi, dan masalah kedisiplinan siswa baik dari segi berpakaian dan segi kedatangan yang masih melanggar aturan tata tertib sekolah. Namun hal tersebut tidak menjadi masalah serius, sebab kegiatan pembiasaan tetap berjalan sesuai rencana. Malahan pihak sekolah senantiasa berusaha keras untuk meminimalisir kendala-kendala tersebut dengan meningkatkan kinerja seluruh elemen yang ada di lingkungan sekolah. 
5) Hasil Program Budaya Religius Terhadap Perilaku Siswa

Setelah dilaksanakannya program budaya religius di SMPN 44 Bandung, siswa jadi memiliki tambahan pengetahuan tantang agama Islam, dan juga memiliki akhlak yang baik. Nilai-nilai pendidikan karakter dalam program budaya religius di sekolah sangat perlu diterapkan pada proses pembelajaran. Proses pembelajaran tidak hanya dilakukan di dalam kelas saja, akan tetapi juga harus dilakukan di luar kelas dengan menanamkan nilai-nilai karakter religius melalui pelaksanaan program budaya religius di SMPN 44 Bandung.

Namun upaya tersebut tidak akan berjalan mulus apabila guru PAI sebagai penanggung jawab utama proses pembelajaran tidak berkeinginan untuk melaksanakannya dengan baik. Dari proses pelaksanaan budaya religis tersebut terdapat hasil yang cukup bagus, dimana siswa bisa memiliki kebiasaan beribadah tepat waktu, senantiasa selalu melakukan shalat berjama'ah di Masjid, memiliki hafalan quran, jadi sering bershalawat dan berzikir kepada Allah Swt, hafal bacaan Asmaul Husna, memiliki jiwa toleransi kepada siswa yang non muslim, peduli terhadap lingkungan, dan memiliki sikap santun terhadap orang tua, guru, dan sesama teman, serta yang terpenting ia bisa memiliki akblakul karimah (akhlak yang baik). Disinilah guru PAI dituntut untuk berperan aktif melakukan bimbingan, dorongan dan motivasi dalam menjalankan kegiatan pembiasaan yang sudah di programkan oleh sekolah. Hal tersebut demi tercapainya kualitas pendidikan yang tidak hanya sekedar mentransfer ilmu pengetahuan tetapi juga mentransfer nilai-nilai karakter religius terhadap siswa.

Dalam penelitiannya Muhlison (2014, hal. 47) menyimpulkan bahwa sebagai seorang pendidik, guru PAI tidak sematamata menjadi transformer of knowledge, akan tetapi juga menjadi transformer of value yang mampu membimbing dan menuntun siswa kearah yang lebih baik. Selain itu hasil riset Shabir (2009, hal. 222) juga menyimpulkan bahwa seiring kemajuan teknologi dan informasi yang begitu pesat, guru PAI tidak hanya sekedar penyaji informasi, akan tetapi juga menanamkan nilai-nilai budi pekerti kepada anak didiknya.

Mengingat begitu pentingnya pendidikan budaya religius bagi peserta didik dalam proses membentuk sikap dan kebiasaan positif, tentunya tidak terlepas dari peran utama guru PAI. Sebab ia merupakan motor atau penggerak dari program budaya religius tersebut. Disamping itu, ia memiliki tanggung jawab yang berat dalam mendidik, membina, menuntun peserta didik agar memiliki akhlak yang baik. Lalu ia juga harus bisa mengkonstruksi ilmu pengetahuan secara sistematis terhadap peserta didik dalam bentuk ide, wawasan, kecakapan, dan pengalaman yang berkaitan dengan hakikat ilmu, serta ia dituntut juga untuk memiliki pengetahuan lebih yang diyakini mampu menghantarkan anak didik kearah kesempurnaan dan kemandirian (Sada, 2015, hal. 96).

Cukup banyak perubahan yang terjadi pada diri siswa, mulai dari segi akhlak yang menjadi lebih baik, hingga segi wawasan pengetahuan tentang agama Islam menjadi semakin luas. Selain itu, bukan hanya di sekolah saja dampak 
pengaruh yang dirasakan, akan tetapi juga di dalam kehidupan keluarganya juga menjadi lebih baik. Hal tersebut berani didakwakan karena adanya laporan dari para orang tua siswa kepada pihak sekolah yang mengatakan bahwa anaknya mulai ada perubahan perilaku menjadi lebih baik, semenjak mulai diterapkannya program ini di belasan tahun silam.

Keberhasilan program budaya religius ini tentunya tidak terlepas dari dukungan berbagai materi dan metode yang diterapkan oleh para guru PAI dan juga guru-guru yang lain yang senantiasa bekerja keras menjalankan program ini. Dengan rasa kasih sayang yang diberikan guru kepada para siswa di SMPN 44 Bandung ini, memiliki pengaruh yang sangat besar terhadap hasil yang dicapai dari pelaksanaan program tersebut.

Selama ini peneliti melihat penyampaian materi dan penggunaan metode yang digunakan para guru PAI di SMPN 44 Bandung sudah cukup bagus dan memberikan aura positif bagi perubahan-perubahan perilaku siswa. Meskipun hasilnya belum mencapai derajat maksimal, perubahan perilaku siswa hari demi hari mulai tampak lebih baik. Dari data yang didapatkan peneliti maka disimpulkan bahwa program budaya religius di SMPN 44 Bandung cukup efektif dan berhasil dalam membangun kebiasaan-kebiasaan yang positif. Keberhasilan dari pencapaian tersebut dapat dilihat dari perubahan perilaku siswa yang telah mengikuti program budaya religius di SMPN 44 Bandung melalui kegiatan pembiasaan.

Dengan adanya hasil yang dapat terlihat dari program budaya religius di SMPN 44 Bandung, maka peneliti merasa bahwa peran guru PAI dalam menerapkan program ini cukup berhasil untuk merubah akhlak atau perilaku siswa yang sebelumnya kurang baik menjadi baik. Para siswa terlihat rajin beribadah, terbukti dengan kebiasaan-kebiasaan siswa melakukan shalat berjama'ah di Masjid. Selain itu, para siswa juga terlihat lebih sopan kepada yang guru, berjiwa toleransi kepada siswa yang non muslim, lebih terlihat disiplin, senantiasa menerapkan budaya $5 \mathrm{~S}$ dalam berbagai aktivitas, lebih agamis, mandiri, kreatif, jujur, bersahabat dengan siapapun, peduli terhadap lingkungan sekitar, peduli sosial, menghargai prestasi, dan lebih bertanggung jawab.

\section{KESIMPULAN}

Berdasarkan hasil penelitian tentang upaya guru PAI dalam meningkatkan budaya religius di SMPN 44 Bandung, diperoleh kesimpulan sebagai berikut:

1. SMPN 44 Bandung membuat program Budaya Religius bertujuan agar semua siswa dan siswi tidak hanya datang ke sekolah untuk meningkatkan sisi intelektualitas saja namun juga meningkatkan sisi spiritual atau karakter.

2. Latar belakang pembuatan program budaya religius ini tidak terlepas dari rasa kekhawatiran Kepala Sekolah (Bapak Agus Suhara) terhadap anak didiknya, karena pada saat itu situasi dan kondisi sekolah sedang memiliki pengaruh moral yang buruk. Selain itu pembuatan program ini ialah merupakan salah satu upaya untuk kembali menerapkan model pendidikan di zaman Rasulullah saw.

3. Kegiatan pembiasaan yang dilakukan oleh seluruh warga sekolah 
merupakan suatu upaya yang dilakukan guru PAI untuk mencegah terjadinya kemerosotan akhlak khususnya di kalangan siswa-siswi, dan umumnya seluruh warga SMPN 44 Bandung supaya menjadi insan yang taat terhadap ajaran agama, dan bisa menerapkan nilai-nilai Islam dalam kehidupan sehari-hari. Proses pelaksanaan kegiatan pembiasaan terbagi menjadi empat bagian, yaitu di antaranya: 1) pembiasaan harian; 2) pembiasaan mingguan; 3) pembiasaan bulanan; dan 4) pembiasaan tahunan.

4. Dalam pelaksanaan program budaya religius di SMPN 44 Bandung, terdapat beberapa kendala, yaitu di antaranya: a) Masih ada sebagian guru dan yang merasa terganggu waktunya itu dengan pembiasaan ini karena perbedaan faham; b) Kurangnya semangat dan motivasi dari siswa untuk mengikuti kegiatan pembiasaan; c) Masalah kedisiplinan siswa; d) Sempat mendapat penolakan dari para orang tua siswa; e) Masalah sarana prasarana yang kurang mendukung; f) Faktor teknisi yang kurang memadai; dan g)Jumlah tenaga ahli yang terbatas.

5. Dengan melihat hasil dari peran guru PAI meningkatkan budaya religius di sekolah, maka program budaya religius di SMPN 44 Bandung ini terbilang cukup berhasil untuk merubah akhlak atau perilaku siswa yang sebelumnya kurang baik menjadi baik. Buktinya para siswa terlihat rajin dalam beribadah, dan sering ke Masjid untuk melaksanakan shalat berjama'ah. Selain itu, mereka juga terlihat lebih sopan kepada guru, berjiwa toleransi kepada siswa yang non muslim, lebih terlihat disiplin, lebih agamis, mandiri, kreatif, jujur, bersahabat dengan siapapun, peduli terhadap lingkungan sekitar, peduli sosial, menghargai prestasi, dan lebih bertanggung jawab

\section{REFERENSI}

Arikunto, S. (2006). Prosedur Penelitian; Suatu Pendekatan Praktek (4 ed.). Jakarta: Rineka Cipta.

Asmarani, T., Abdussalam, A., \& Surahman, C. (2019). Konsep

Muttaqin dalam al-Qur'an dan Implikasinya Terhadap Tujuan Pendidikan Islam (Studi Analitis Terhadap Konsep al-Muttaqīn dalam Al-Qur'an). Murabby: Jurnal Pendidikan Islam, 2(1), 46-56.

Aulia, L. R. (2016). The Impelementation

Of Religious Values In Character Education For Learners In Grade School Juara Yogyakarta. Jurnal Kebijakan Pendidikan, V(3), 314-323.

Emzir. (2011). Metodelogi Penelitian Kualitatif Analisis Data. Jakarta: Rajawali Press.

Fakhruddin, A. (2014). Urgensi pendidikan nilai untuk memecahkan problematika nilai dalam konteks pendidikan persekolahan. Jurnal Pendidikan Agama Islam, 12(1), 79-96. Fakhrudin, A. (2011). Prinsip-prinsip Manajemen Pendidikan

Islam. Ta'lim, 9(2), 211.

Fathurrohman, M (2016).

Pengembangan Budaya Religius

Dalam Meningkatkan Mutu

Pendidikan. Ta'allum, 4(1), 19-42.

Hamdi, A. S., \& E. Bahruddin. (2014). 
Metode Penelitian Kuantitatif Aplikasi Dalam Pendidikan. (A. Anas, Ed.) (1 ed.). Yogyakarta: deepublish.

Kurniaman, O., \& Noviana, E. (2017). Penerapan Kurikulum 2013 Dalam Meningkatkan Keterampilan, Sikap, dan Pengetahuan. Jurnal Primary Program Studi Pendidikan Guru Sekolah Dasar Fakultas Keguruan dan Ilmu Pendidikan Universitas Riau, 6(2), 389_ 396.

Kusnawan, A. (2010). Perencanaan Pendidikan Tinggi Dakwah Islam. Jurnal Ilmu Dakwah, 4(15), 899-920.

Moleong, L. J. (2005). Metodologi Penelitian Kualitatif. Banda Aceh: Remaja Rosdakarya.

Muchith, M. S. (2016). Guru PAI Yang Profesional. Quality Journal, 4(2), 217-235.

Muhaimin. (2006). Nuansa Baru Pendidikan

Islam: Mengurai Benang Kusut Dunia Pendidikan (1 ed.). Jakarta: Raja Grafindo Persada.

Muhlison. (2014). Guru Profesional (Sebuah Karakteristik Guru Ideal Dalam Pendidikan Islam). Jurnal Darul Ilmi, 2(2), 46-60.

Nagy, P. T. (2010). Education and Religiosity in Budapest at the Millennium. Journal Social Compass, 57(1), 60-82. https://doi.org/10.1177/003776860 9355538

Nasir, M. (2013). Profesionalisme Guru Agama Islam (Sebuah Upaya Peningkatan Mutu Melalui LPTK). Dinamika Ilmu, 13(2), 189-203.

Putra, K. S. (2015). Implementasi Pendidikan Agama Islam Melalui Budaya Religius (Religious Culture) di Sekolah. Jurnal Kependidikan, III(2), 14-32.
Sanusi, H. P. (2013). Peran Guru PAI Dalam Pengembangan Nuansa Religius Di Sekolah. Jurnal Pendidikan Agama Islam-Ta'lim, 11(2), 143-152.

Sauri, S. (2003). Pengembangan Strategi Pendidikan Berbahasa Santun di Sekolah. Mimbar Pendidikan, XXII(1), 45-53.

Siregar, F. R. (2017). “ Nilai-Nilai Budaya Sekolah dalam Pembinaan Aktivitas Keagamaan Siswa SD IT Bunayya Padangsidimpuan ." Jurnal Pusat Studi Gender dan Anak, 1, 1-11.

Somantri, M. (2014). Perencanaan Pendidikan. (N. Januarini, Ed.) (1 ed.). Bogor: IPB Press.

Spira, S. C., Studies, R., Davis, Lady, Hospital, I. G., Wainberg, M. A., Centre, A., ... Hospital, I. G. (2004). Opinion Jewish religious ethics mandate access to antiretroviral drugs in developing countries. JLAPAC, 3(1), 7-11.

Sugiyono. (2012). Metode Penelitian Bisnis. Bandung: Alfabeta.

Supriyanto. (2018). Strategi Menciptakan Budaya Religius di Sekolah. Jurnal Tawadhu, 2(1), 469-489.

Wening, S. (2012). Pembentukan Karakter Bangsa Melalui Pendidikan Nilai. Jurnal Pendidikan Karakter, (1), 55-66. 